\title{
Risk assessment studies on HLA association with drug induced hypersensitivity caused by anti tuberculosis drugs - an in silico approach
}

\author{
Prashant Saxena*, Jemmy Christy
}

From 2nd International Science Symposium on HIV and Infectious Diseases (HIV SCIENCE 2014)

Chennai, India. 30 January - 1 February 2014

\section{Background}

Studies have conferred that there is a strong genetic association between HLA alleles and susceptible drugs leading to hypersensitivity. Patients with HIV have the highest risk of developing active Tuberculosis. So here we studied the genetic predisposition to anti-tuberculosis drugs as a model to study the pathological role of HLA alleles in drug hypersensitivity.

\section{Method}

Here we aimed to find out the anti-tuberculosis drugs like sulfasalazine, allopurinol, streptomycin and oflaxacin as candidate drugs and their binding sites on HLA alleles which are prevalent among Indian population like HLA-A*02:06, HLA-B*57:01, HLA-A*02:01 and HLA$\mathrm{A}^{*} 02: 03$ using docking simulation method via Autodock.

\section{Result}

Anti-tuberculosis drugs can bind within the peptide binding grooves of HLA-B*57:01, HLA-A*02:06 and HLA-A*02:03 alleles and thereby alter its specificity. In the docking simulations, the interactions were found between HLA-A*02:01 and sulfasalazine, streptomycin , oflaxacin at Asp54, Ile237, Glu236, Lys267, Glu256, Thr238 And Val255 with $-6.43 \mathrm{kcal} / \mathrm{mol},-5.86 \mathrm{kcal} / \mathrm{mol}$ and $-5.83 \mathrm{kcal} / \mathrm{mol}$ binding energy. HLA-A*02:06, HLA$B * 57: 01$ and HLA-A*02:03 have interaction with oflaxacin at Arg6, Lys58, Tyr51 and Arg72 with binding energies of $-5.72 \mathrm{kcal} / \mathrm{mol},-5.79 \mathrm{kcal} / \mathrm{mol}$ and $-5.15 \mathrm{kcal} / \mathrm{mol}$ respectively.

\section{Conclusion}

The ultimate translation of this knowledge of how Antituberculosis drugs interact with HLA would be applicable to preclinical drug screening programs to improve the safety and cost effectiveness of drug design and development.

Published: 27 May 2014

\section{doi:10.1186/1471-2334-14-S3-P45}

Cite this article as: Saxena and Christy: Risk assessment studies on HLA association with drug induced hypersensitivity caused by anti tuberculosis drugs - an in silico approach. BMC Infectious Diseases 2014 14(Suppl 3):P45.

*Correspondence: prashant347@gmail.com

Department of Bioinformatics, Sathyabama University, Chennai-600119, India

Submit your next manuscript to BioMed Central and take full advantage of:

- Convenient online submission

- Thorough peer review

- No space constraints or color figure charges

- Immediate publication on acceptance

- Inclusion in PubMed, CAS, Scopus and Google Scholar

- Research which is freely available for redistribution
( Biomed Central 